DOI: $10.17516 / 1997-1370-0586$

УДК 330.15

\title{
Introducing Norwegian Oil and Gas Model in Russia: Institutional Challenges
}

\author{
Valeriy A. Kryulkov*a and Andrey K. Krivorotov ${ }^{\mathrm{b}}$ \\ anstitute of Economics and Industrial Engineering of SB RAS \\ Novosibirsk, Russian Federation \\ ${ }^{b}$ Odintsovo branch, Moscow State Institute of International Relations \\ (MGIMO University) \\ Odintsovo, Moscow District, Russian Federation
}

Received 12.03.2020, received in revised form 06.04.2020, accepted 13.04.2020

\begin{abstract}
While the Norwegian oil and gas model is a popular reference case in Russia, one should realize that it has developed over time within a specific national, historical and institutional context. The core role in this model belongs to the Norwegian state in terms of resource management, establishing the regulatory framework, massive taxation, and actual involvement in the business, first of all through the national petroleum company Statoil/Equinor. Equinor has evolved since 1972 from a modest carried partner to a large streamlined corporation, operating in 35 countries and focusing heavily on global technological leadership. All investors, either state-owned or private, are put under the same public scrutiny and stimulated with non-fiscal incentives, such as political stability, predictable regulations and abundant geological information. This large scale government intervention relies on proactive, professional and incorrupt bureaucracy enjoying broad powers.

Much of this practice is not common and may not be introduced directly in Russia, which tends to limit the role of public servants and rely on big state corporations. However, the Norwegian experience seems very relevant for the urgently needed overhaul of the Russian energy policies, both offshore and in Western Siberia.
\end{abstract}

Keywords: Norway, oil and gas industry, governance, state-owned company, innovations.

The article was written with financial support of the Russian Science Foundation (grant No. 19-18-00170).

Research area: economics; world economy.

Citation: Kryukov, V.A., Krivorotov, A.K. (2020). Introducing Norwegian oil and gas model in Russia: institutional challenges. J. Sib. Fed. Univ. Humanit. Soc. Sci., 13(4), 529-537. DOI: 10.17516/19971370-0586.

\footnotetext{
(C) Siberian Federal University. All rights reserved

* Corresponding author E-mail address: kryukov@ieie.nsc.ru, krivorotov@starlink.ru ORCID: 0000-0002-7315-6044 (Kryukov); 0000-0001-8983-5378 (Krivorotov)
} 
References to the positive Norwegian experience are very common in the domestic Russian debate on oil and gas policies. Characteristically enough, this experience is praised by politicians of both the right and the left wings, who tend each to single out some specific features.

The recent initiatives by Deputy Prime Minister Yury Trutnev are a good example. In a letter sent to President Vladimir Putin in October 2019, he called for a more active development of the Russian Arctic shelf, which under the present Russian law is only allowed to government-owned companies with no less than five years of experience in continental shelf operations. This legal clause essentially limits the access to the Arctic shelf to merely two state companies, Gazprom and Rosneft, which already hold licenses for some 85 per cent of its total area. Mr. Trutnev advocated the use of the Norwegian model, claiming that the national oil company gets only 30 per cent of each project there, while the rest belongs to private Norwegian and foreign companies (Podobedova, Dergachev, 2019).

It is clear, however, that any national business environment has developed within a given economic, social and institutional framework, which is often country specific and may not be transferred efficiently piece by piece into other countries. Russia has experienced this repeatedly, most recently by introducing liberal monetarism inspired by the IMF and Western consultants.

This article aims to give a general outline of the Norwegian petroleum model against a broader historical background, from the viewpoint of its applicability in the respective Russian context.

\section{Evolution of the Norwegian model}

First of all, the Norwegian petroleum model is not static. It has been developing over nearly six decades, together with the industry itself, and has gone through several distinct stages where it faced shifting policy goals.

Its history started in late 1962, when Phillips Petroleum, an American oil company, requested a monopoly right to explore and develop the Norwegian continental shelf. This application represented a major challenge to Norway which possessed zero experience in the industry, while it still remained unclear whether or not there were any resources there. However, within a short time range, the Norwegian authorities managed to make several principal decisions laying the cornerstones of their future oil and gas model. In 1963, the state was declared the owner of all seabed resources, with the aim of using these for the benefit of the whole people. Norway joined swiftly the 1959 Hague Convention on Continental Shelf and agreed on delimitation of the North Sea shelf south of $62^{\circ} \mathrm{N}$. Exploration and development were allowed in the whole of this area in 1965, when several dozen blocks were licensed for the first time to a handful of global companies.

From the early days, the Norwegian authorities pursued a cautious approach to shelf development and relied on strong national control. Among others, they rejected the idea of introducing license auctions (like in the UK shelf) to avoid speculative investments (Gøthe, 1988).

The unique Ekofisk oilfield was discovered in late December 1969 and commissioned in 1971. Just four years later Norway already turned into a net exporter of oil. The authorities realized that the process was creating both new opportunities and new risks.

The turning point came in 1972, when Norway first charted its oil and gas policy, established a $100 \%$ state-owned oil company, Statoil, and the key government agency, the Norwegian Petroleum Directorate. The subsequent period through the end of the $20^{\text {th }}$ century was marked by a rapid buildup of national petroleum extraction and service capabilities, supported by deliberate protectionist policies by the government. The administrative mechanism was being shaped in parallel, which resulted in 1985 and 1996 in the adoption of the first and the second (still valid) editions of the basic Petroleum Act, respectively. The oil and gas production was growing rapidly, by the early 1980 s they already stood for over one half of the national commodity exports. Norway turned into a major supplier of fossil fuels to the European market and the leading producer of gravity based concrete offshore platforms. The 
trade balance and public revenues improved dramatically and the nation witnessed, for the first time ever, a lasting budgetary surplus.

The government set a political aim of maintaining the petroleum production within 90 million tons oil equivalent (mtoe), although it turned out difficult due to the many 'pro-drilling' interests involved.

Meanwhile, the petroleum industry still consisted of a limited number of players exploiting predominantly the national resource base, first and foremost in the southern part of the North Sea, which became increasingly depleted. The industry moved northwards slowly, exploratory drilling in the Norwegian Sea started in 1981 and in the Barents Sea in 1987.

In the early 2000 s, Norwegian petroleum policies underwent major changes. The government had serious concerns that upstream production in Norway was about to peak, so it set the dual policy goal of extending the nation's oil age and expanding its worldwide operations. While in the $20^{\text {th }}$ century the consecutive Norwegian governments tried to limit the petroleum production, now they do their utmost to maintain it by enhancing competition, development of marginal fields and increasing oil recovery ratios. This policy remains true also today, despite the very strong climatic focus on low carbon transition and renewable energy.

\section{The key feature of active government}

The Norwegian oil and gas model operates in a specific institutional context, which includes strong communal traditions of solidarity and mutual support, Lutheran respect to hard work, a powerful and transparent public administration, and an influential civil society.

This system includes several key elements, which are closely interrelated and should be regarded as a whole. These include, among other:

- public property right for all resources of the Norwegian continental shelf, which are supposed to benefit the whole nation;

- a flexible administrative licensing system, whereby a license is issued to a group of investors by the competent public authority (the Norwegian Petroleum Directorate), while license holders are entitled to sell their stake to another companies later on,
- prequalification of investors who are willing to work in the Norwegian continental shelf, which serves as a filter against non-serious profit seekers,

- a national petroleum company (Statoil, renamed Equinor in 2018) receiving majority stakes in all blocks ever since it was established in 1972 ,

- stringent health, safety and environment (HSE) regulations, which are pursued rigorously by the respective government agencies,

- a non-discriminatory, but high taxation of oil companies,

- a deliberate policy to develop the domestic research, education and industry base to serve the oil and gas complex, thus creating a diversified nationwide cluster,

- a sovereign wealth fund to accumulate and sterilize the public oil revenues (which became the sole piece of the Norwegian experience to be introduced in Russia in full, when the Stabilization Fund was established).

This list demonstrates the core role played by the Norwegian state, in several capacities.

First, as a public power representing the national interest, it is in charge of resource management, including notably regional geological surveys, resource appraisals, licensing and supervising the companies' compliance. The key powers, like enacting petroleum legislation, opening new shelf areas for exploration and development, and approving the Plans for Development and Operation for each oil and gas field, are reserved for the Storting (Parliament), as the supreme elected representative body.

Second, the government sets the regulatory framework, both for the petroleum industry and the related supply businesses. Norway has always welcomed foreign investments, but subject to tight public control to ensure budgetary revenues, technology transfer, development of national capabilities both off- and on-shore, and high HSE standards.

Third, as a fiscal authority, the state captures a large portion of the oil rental revenues. The government take has always been extremely high, up to $85 \%$ (now $78 \%$ ) of net corporate income. This is well in line with the Norwegian social democratic traditions of a powerful pa- 
ternalist state, which redistributes some $60 \%$ of the GDP through the state budget.

Fourth, the Norwegian state is also involved in the oil business as such through the state-owned enterprises.

It is noteworthy that such approach is in strict contradiction to the liberal economic model pursued by the Russian governments ever since the breakup of the Soviet Union and the start of the economic reforms in early 1992.

\section{State petroleum company:}

up the steep learning curve

Statoil was established as a key tool for developing national petroleum competence. To the favor of the Norwegians, they acknowledged from the outset that they had to master a brand new business, and they have always been willing to acquire new knowledge and experience. Thus, the history of Statoil/Equinor may be roughly summed up as follows:

1972-1985 - learning the basics of oil and gas business with a strong governmental backing. The principal method was 'learning by doing'. Statoil received $50 \%$ or more of stakes in all offshore licenses granted, but it acted as a so-called carried partner: its portion of investments was covered by the license partners, while it received its share of any revenues. In this respect, Statoil enjoyed preferential treatment even compared to Norsk Hydro, a large fertilizer and aluminum producer, which also entered the oil business in the 1960s. The state held nearly $50 \%$ of its shares, but it had to do everything at its own cost and risk. (Skjeldal, Berge, 2009).

1985-2001 - raising to the national champion. During the period, Statoil, as well as Hydro, acquired high-level competence in petroleum geology, exploration, development, and operations, with a strong focus on Norwegian continental shelf. The companies got unmatched practical experience in offshore operations under harsh climatic conditions and started their first, rather modest, international operations.

2001-around 2015 - consolidating national oil business, learning international management, pioneering Arctic offshore operations. Statoil was partly privatized, starting with
2001, and entered listings at the New York and Oslo Stock Exchanges, to make its operations more market-minded.

In 2007, it merged with (although, in practical terms, rather acquired) Hydro's oil business. Soon before the merger, Hydro and Statoil had delivered strategic field developments (Ormen Lange and Snøhvit) positioning themselves in the forefront of seabed completion globally. Snøhvit, despite its numerous problems, was of special importance as the first-ever development offshore Barents Sea and the only LNG plant in Europe, which applied a unique, proprietary liquefaction technology (the Statoil-Linde process).

The united company also rapidly expanded its international portfolio and has now exploration and production assets in 35 countries around the globe. The growing public exposure and overseas operations dramatically transformed Statoil into a streamlined corporation with little bureaucracy. It became compatible to international majors in terms of corporate governance, project management, and financial engineering.

2015-now - transforming towards a diversified energy company, assuring global technological leadership in northern and Arctic offshore operations, pioneering low-carbon transition, transferring petroleum technologies and skills to other businesses.

Under the present day climate agenda, oil and gas are no longer 'trendy' in Norway. Characteristically, Statoil itself asked its shareholders to rename it into Equinor in 2018, getting rid of connotations with both petroleum and the state. Indeed, the company remains committed to oil and gas business and has completed a number of cutting-edge projects, both in the North Sea and the Arctic shelf, like Aasta Hansteen-Polarled (2018), Johan Sverdrup (2020) or Johan Castberg (to be launched in 2024). However, the main public focus today is made on cutting the carbon footprint of the oil and gas projects and developing clean energy solutions like wind and solar power. In the renewables, Equinor is also counting on innovations and technological leadership.

For natural reasons, this 'learning curve' of Statoil/Equinor correlates closely with the 
above-mentioned evolution of the Norwegian oil and gas model as a whole.

The government has also been involved in a continuous learning process as a responsible owner of Statoil. The overall trend has been to allow the company an ever growing independence and market orientation. Since 2004, its CEOs (Helge Lund and Eldar Sætre) have not been former Labor Party functionaries, but skilled managers appointed for their professional merits.

There is an ongoing discussion in Norway, like in Russia, to which extend Equinor, the by far dominant national company, obeys instructions of the government or pursues its own interest (Krivorotov, Finger, 2019). However, the Norwegian state has always made a clear distinction between its roles as the owner of subsoil petroleum resources and the oil company owner. Although Statoil/Equinor enjoys preferential treatment in the license awards, it is also subject to a close public scrutiny in terms of compliance with license conditions, HSE requirements, local content performance etc. Both the company and the government itself came under a harsh criticism from various agencies and NGOs in 2010-2013 for the failed project within carbon capture and storage, which had received heavy budgetary subsidizing as a flagship effort in the Norwegian climate policy. The company's position is also challenged by competitors, which are deliberately encouraged by the government. This differs the Norwegian case from contemporary Russia, where the state seemingly trusts stateowned companies to run whole industries.

Characteristically enough, the above initiatives by Deputy Prime Minister Yury Trutnev on introducing the Norwegian model in the Russian Arctic have resulted in a draft law on State Corporation Rosshelf, tabled for discussion in the very end of 2019. According to the draft, this new institution is going to issue licenses in the Arctic and Far Eastern shelf, to monitor the implementation, as well as to participate with $30 \%$ stakes in all licenses as a commercial entity (Draft Federal Law..., 2019). It would thus be responsible both for the resource management and the use of resources, essentially supervising itself. This is unthink- able in Norway, where the two functions are divided strictly between the Petroleum Directorate and Equinor.

\section{Private investors and active government: striking a balance of interests}

International oil giants, who tend to follow their own rules all over the world, discovered early on that in Norway they could not ignore (or simply bribe) the authorities and lobby their decisions freely. The Norwegians have for decades demonstrated a strong political will and pursued long-term strategic goals, which have generally stretched beyond the industry as such.

Meanwhile, the Norwegian state has avoided arbitrary behavior, but instead practiced a broad outreach to investors: the legal and policy framework is tough, but not too stringent to make Norway unattractive. The Scandinavian tradition of mutual respect and fair compromises has definitely played an important role in framing the national petroleum investment regime.

In a slightly simplistic way, one may say that an investor evaluates any project, first of all, by comparing the expected return on investments, usually the IRR, and the related risks. If this ratio is marginal (which is very often the case in Norwegian, as well as in Russian petroleum industry), the government may stimulate investments in two principal ways. The first one is to increase the investor's return through subsidizing, tax reliefs, etc., while maintaining the level of business risks. The other one is not to use financial levers, but in turn reduce the investor's risks by enhancing the investment climate, spreading information, developing the infrastructure, etc.

In Norway, the authorities have traditionally stuck to the second option. The exceedingly high government take is compensated by the nation's political stability, transparent predictable legislation, massive geological surveys (done among other by government agencies), strong law enforcement, and short distances to European markets.

There are also several channels and contact spots facilitating regular interaction between the government and companies. For ex- 
ample, in 2001, the Ministry of Oil and Energy initiated a joint discussion forum, Oil and gas for the 21st century (OG21) involving government agencies, business and researchers. OG21 develops technology strategies which are updated once every five years (last time in 2016).

The broad national consensus on petroleum policies has also contributed to making Norway attractive for international companies. Indeed, there are lasting 'hot political potatoes' like the scope of public involvement in the oil business or the 2001 moratorium on petroleum exploration off the fish-rich Lofoten and Vesterålen islands. In general, however, Norwegian politicians tend to think long-term and seek compromises across the party lines on issues of national importance, especially those involving foreign relations. Thanks to that, the numerous cabinet shifts over the decades were not affecting the oil companies' operating conditions significantly.

The principles of the Norwegian petroleum taxation are universal and non-discriminatory. No individual tax reliefs have ever been granted, except for the above mentioned groundbreaking Snøhvit project. The case of Norway thus stands in a sharp contrast to the popular Russian belief that investors, either foreign or domestic, need tax incentives to invest in marginal fields. Unlike in Russia or the UK, oil companies in Norway did not plea to have their tax burden reduced even after the dramatic oil price falls in 2008 and 2014.

Such impartial tax enforcement has also strong practical effects on the state company's behavior. If Statoil/Equinor faces a complicated field, it would increase its R\&D efforts to make it viable. The big Johan Castberg oilfield offshore Barents Sea is a good example: once Statoil was appointed its operator, it changed the technical concept and managed to cut the development costs by half and the breakeven oil price from $\$ 80 /$ barrel to $\$ 35 /$ barrel within a few years (Statoil 2017). In Russia, a large petroleum company (be it state-owned Rosneft, Gazprom, or private Novatek) would in a similar situation apply to the government for earmarked tax reliefs. As a result, Equinor is an acknowledged technological leader in the Norwegian shelf and globally, creating strong ripple effects for the national supply industry as well. Meanwhile, the Russian mineral resources complex, including notably oil and gas industry as its backbone component, lags behind other Russian industries in innovative activities, while Russia underperforms as a whole, compared to other nations (Kryukov, Tokarev, 2019).

\section{Trust to civil servants}

\section{as a macroeconomic asset}

By acquiring an active regulatory role, the Norwegian state has also undertaken heavy administrative duties. Indeed, it is much easier to charge the Russian petroleum extraction tax at a flat rate than to define a fair oil price for each field on a quarterly basis, like the Norwegian Petroleum Price Board does to calculate taxable operating income. A Norwegian licensing round, whereby each license is split by the Petroleum Directorate according to the companies' proposals and potential, is a much more sophisticated (and subjective) procedure than a simple lease auction.

This implies an active and creative role of the civil servants - unlike Russia, where public employees are, for obvious reasons, regarded as potentially corrupt, and the human factor in administrative procedures is deliberately reduced.

Characteristic features of the Norwegian petroleum bureaucracy include high qualification, willingness to learn, patriotism and virtually zero corruption. The latter tradition, founded in the very early days of the country's oil policy by Jens Evensen, its main architect, is of crucial importance, as it gives the necessary confidence to the state, the investors and the broad public. For example, despite the closeddoor nature of the licensing rounds, companies have never challenged their results, as they trust the impartial award procedure.

The high professionalism of the civil servants has also allowed the public decision makers to implement various policies without amending the formal rules. In accordance with the valid political guidelines, state agencies could either restrict or ease up the access of smaller companies to the continental shelf, either limit or stimulate upstream production. 
The large public stake in each license (either directly or through Equinor) is equally not stipulated in law. There is no doubt that such system is much more flexible and adaptable than the one based on heavy, impersonalized procedures and very detailed legislation, which has to be amended every time.

\section{Why just the shelf?}

It is also noteworthy, that while Norway has offshore oil resources only, its experience is equally relevant to the Russian onshore, as well. For example, the North Sea has a number of common features with Western Siberia, as both provinces have entered into the maturity stage. They are well developed, with lots of infrastructure in place and well known regional geology. However, many of the existing fields are now heavily depleted, new big finds being unlikely. Both provinces require badly an influx of new technological and organizational innovations in order to extend the life cycles of the fields, enhance the oil recovery ratios and eventually develop non-conventional resources.

The Norwegian authorities reacted to this challenge by adjusting their policies to promote competition and diversity of actors. Since 2000, a total of 122 domestic and foreign oil companies have been prequalified by the Petroleum Directorate to work and operate offshore fields, therein 30 in the boom years 2006 and 2007. Many of these were small or medium-sized high-tech startups (so-called mosquitoes), willing to develop small reservoirs or mature fields in the tail phase, which are of less interest for the big players. The government introduced a simplified fast-track procedure to issue clearances for development of minor deposits, often done by subsea tie-backs to the existing infrastructure.

Statoil disapproved publicly of this development. Helge Lund, the then CEO, criticized the authorities harshly in 2008, stating that the 'mosquitoes' could not maintain production and geological exploration under crisis, as they did not possess necessary financial strength. Nevertheless, the smaller companies did play an important role in reversing the fall in petroleum production. They helped monetize or extend life cycles of several fields making NCS more competitive. Lundin Norway, a Swedish medium-size independent producer, even outclassed Statoil by making a major find in a North Sea block Statoil had abandoned.

The massive development and introduction of new technologies has helped to revert the fate of many old fields in the Norwegian sector of the North Sea. Their actual production profiles are well above the planned curves, with the average nationwide oil recovery ratio exceeding $50 \%$. Challenged by the smaller competitors, Statoil surprisingly decided not to abandon the famous Ekofisk field and to extend its lifecycle beyond its present license term of 2028.

A diversity of actors is equally badly needed in Russia. With the oil recovery ratio in new Russian fields not exceeding 30\%, the country has an enormous potential of increasing the domestic oil production in the mature areas, making an efficient use of the existing infrastructure. The state-owned majors alone lack the required incentives to introduce innovations. A variety of big, medium-sized and small businesses, each one with its own technological profile and strengths, would help utilize the resources better, introducing advanced oilfield technologies and giving rise to $R \& D$ efforts and new service industries (Shafranik, Kryukov, 2016).

\section{Conclusion}

As our analysis shows, the high efficiency of the Norwegian model is based on a number of principles, which are rather alien to contemporary Russia. These include a massive governmental intervention, predominant use of non-fiscal incentives, a vigorous bureaucracy, the government's 'trust but verify' relation to the state oil company, active industrial policies in regard of both the petroleum industry and the supply branches, etc.

Attempts to acquire certain pieces of the Norwegian model ignoring this context may bring about opposite effects. For example, the proposed Rosshelf corporation, a monopolist free for any public supervision, would easily tend to become a mere subsoil rentier, holding minority positions in all offshore projects, 
cashing in revenues and having little motivation to learn the business or improve its performance.

This being said, the Norwegian experience is definitely interesting and highly relevant for Russia, given a number of similar challenges and common traditions. The Russian energy policies require a major overhaul badly in order to harmonize public and private interests, to facilitate a massive modernization of the industry, and to spur innovations generating major spin-offs for national research and engineering.
A thorough study of the Norwegian model may bring about very useful inputs in this regard, and presumably not that much in terms of specific institutions but of fundamental policy features, subject to necessary adaptation. These include among other long term planning, selective protectionism combined with strong incentives for innovation, stimulating R\&D and advanced technologies, promoting diversity and competition, and much stronger involvement of public opinion (business and research communities, local authorities, NGOs, etc.)

\section{References}

Draft Federal Law... (2019). Available at: https://regulation.gov.ru/projects\#npa=98535 (accessed 28 February 2020).

Gøthe, O.Chr. (1988). Ærlig talt! Om industriskandaler, statsråder og annet [Frankly speaking! On industry scandals, ministers, etc,]. Oslo, Tiden Norsk Forlag, 216 p.

Krivorotov, A., Finger, M. (2019). State-Owned Enterprises in the Arctic. In Global Arctic Handbook. DOI: $10.1007 / 978-3-319-91995-94$.

Kryukov, V.A., Tokarev, A.N. (2019). Contemporary Features of Innovative Development of the Russian Mineral Resource Complex. In J. Sib. Fed. Univ. Humanit. Soc. Sci., 12(12), 2193-2208. DOI: 10.17516/1997-1370-0518.

Podobedova, L., Dergachev, V. (2019). Trutnev predlozhil dopustit' inostrantsev na shel'f po norvezhskoy modeli [Trutnev propose allowing foreigners to enter the shelf applying Norwegian model]. In $R B C$ daily, August 19.

Skjeldal, G., Berge, U. (2009). Feber. Historia om norsk olje og gass [The Rush. Norwegian Oil and Gas History]. Oslo, Cappelen Damm, 326 p.

Shafranik, Yu.K., Kryukov, V.A. (2016). Neftegazoviy sektor Rossii: trudniy put' k mnogoobraziyu [Russia's oil and gas sector: the hard path to diversity]. Moscow, Novosibirsk, Pero, $272 \mathrm{p}$.

Statoil (2017) Available at: https://www.statoil.com/en/magazine/achieving-lower-breakeven.html (accessed 28 February 2020). 


\title{
Внедрение норвежской модели организации нефтегазовой отрасли в России: институциональные вызовы
}

\author{
B.А. Крюков \\ ${ }^{a}$ Институт экономики \\ и организации промышленного производства СО РАН \\ Российская Федерачия, Новосибирск \\ ${ }^{6}$ Одинцуовский филиал Московского государственного института \\ международных отношений (университета) \\ Российская Федераџия, Московская область, Одиниово
}

\begin{abstract}
Аннотация. Хотя норвежская нефтегазовая модель является популярным примером успешной организации отрасли, которую многие воспринимают как один из возможных эталонов для внедрения в России, следует понимать, что она развивалась с течением времени в рамках конкретного национального, исторического и институционального контекстов. Ключевая роль в этой модели принадлежит Норвежскому государству с точки зрения управления ресурсами, создания нормативной базы, налогообложения и фактического участия в бизнесе в первую очередь через национальную нефтяную компанию Statoil/Equinor. C 1972 года Equinor превратилась из скромного партнера в крупную корпорацию, работающую в 35 странах и уделяющую большое внимание мировому технологическому лидерству. Все инвесторы, как государственные, так и частные, подконтрольны обществу и стимулируются нефискальными стимулами, такими как политическая стабильность, предсказуемое регулирование и изобилие геологической информации. Такое широкомасштабное государственное вмешательство опирается на активную, профессиональную и неподкупную бюрократию, обладающую широкими полномочиями.

Большая часть этой практики не распространена и не может быть внедрена непосредственно в России, которая, какправило, ограничивает роль государственных служащих и опирается на крупные государственные корпорации. Однако норвежский опыт представляется весьма актуальным для срочного пересмотра российской энергетической политики как на шельфе, так и на Востоке России.
\end{abstract}

Ключевые слова: Норвегия, нефтегазовая промышленность, управление, государственная компания, инновации.

Статья подготовлена при финансовой поддержке Российского научного фонда (грант № 19-18-00170).

Научная специальность: 08.00.00 - экономические науки; 08.00.14 - мировая экономика. 